\title{
Massive granitoid generation in Central Asia: Nd isotope evidence and implication for continental growth in the Phanerozoic
}

1. Géosciences Rennes, Université de Rennes 1, 35042 Rennes Cedex, France (e-mail: jahn@ univ-rennes1.fr)

2. Department of Geology, Changchun University of Science \& Technology, Changchun 130061, China

3. Department of Geology, Peking University, Beijing, China

The Central Asian Orogenic Belt (CAOB), also known as the Altaid Tectonic Collage, is characterized by vast distribution of Paleozoic and Mesozoic granitic intrusions as well as basaltic to rhyolitic volcanics. The granitoids have a wide range of compositions and roughly show a temporal evolution from calc-alkaline, alkaline to peralkaline series. The emplacement times for most granitic plutons fall between 500 to $120 \mathrm{Ma}$, but only a small proportion of plutons have been precisely dated. In this paper we document the available $\mathrm{Nd}$ isotopic data to advocate that massive juvenile continental crust was generated during the Phanerozoic in Central Asia.

Most Phanerozoic granitoids of Central Asia are characterized by low initial Sr isotopic ratios, positive $\varepsilon_{N d}(T)$ values and young Sm-Nd model ages $\left(T_{D M}\right)$ of 300 to $1200 \mathrm{Ma}$. This is in strong contrast with the coeval granitoids emplaced in some "classic" orogenic belts, such as, the European Caledonides and Hercynides, Cathaysia of SE China and South Korea. The isotope data indicate their "juvenile" character and suggest their derivation from source rocks or magmas separated shortly from the upper mantle. Granitoids with negative $\varepsilon_{N d}(T)$ values also exist, but they occur in the environs of Precambrian blocks and their isotope compositions reflect contamination of the older crust in the magma generation processes.

The evolution of the CAOB is undoubtedly related to accretion of young arc complexes and old terranes (microcontinents). However, the emplacement of large volumes of post-tectonic granites requires another mechanism-probably through a series of processes including underplating of massive basaltic magma, intercalation of basaltic magma with lower crustal granulites, partial melting of the mixed lithologic assemblages leading to generation of granitic liquids, followed by extensive fractional crystallization. The proportions of the juvenile or mantle component for most granitoids of Central Asia are estimated to vary from 70 to 100\%. The recent "discovery" of juvenile crust in many Phanerozoic orogenic belts elsewhere, together with the $C A O B$, may considerably change our views of the continental growth.

\section{Introduction}

The problem of the growth and evolution of the continental crust has always been an important subject of research in earth sciences. The continental crust is distinguished from the oceanic crust by its more evolved and differentiated nature. It consists mainly of rocks of granitoid compositions (sedimentary rocks and gneisses included), accompanied by subordinate amounts of mafic and ultramafic rocks. The continental crust on earth is a unique feature within the entire solar system and the formation of abundant granitoids is undoubtedly related to the presence of water and its interaction with the silicate earth.

The issue of the rate and nature of continental growth has not yet been resolved satisfactorily. On one hand, continents are known to grow by lateral accretion of arc complexes in active continental margins and by vertical underplating of mantle-derived magma, which may be followed by a series of complex processes leading to production of granitoid rocks. On the other hand, continents are progressively destroyed through chemical and physical erosion from the surface, delamination of the lower crust from the bottom (or A-type subduction), and even direct subduction to mantle depths as evidenced from ultrahigh-pressure metamorphic terranes. Thus, much of the continental mass has gone through recycling in a perpetually dynamic earth since its earliest formation in the early Archean (or Hadean). The real debate on continental growth must be focussed on the net growth - the balance between the quantity of crustal material separated from the mantle and the volume of the continent destroyed and recycled back into the mantle. The steady state or no-growth model advocated by Armstrong since 1968 (Armstrong, 1968, 1981, 1991) incorporates the dynamic processes of crustal growth and destruction, and it has stood the test of geochemical mass balance and isotopic arguments. However, the same geochemical and isotopic data have also been used to argue for a net growth of the continents by other authors (e.g., Moorbath, 1978; Taylor and McLennan, 1985, 1995; Stein and Hofmann, 1994). In order to avoid any ambiguity in this paper, the term "continental growth" means production of continental material through a series of mantle-crust differentiation processes. It involves only processes of addition but not destruction or recycling.

Despite the contrasting net-growth models, it is widely agreed that the production of the continental crust was essentially completed in the Precambrian, especially prior to $2.5 \mathrm{Ga}$. The amount of new crust formed in the Phanerozoic has been considered minor or 


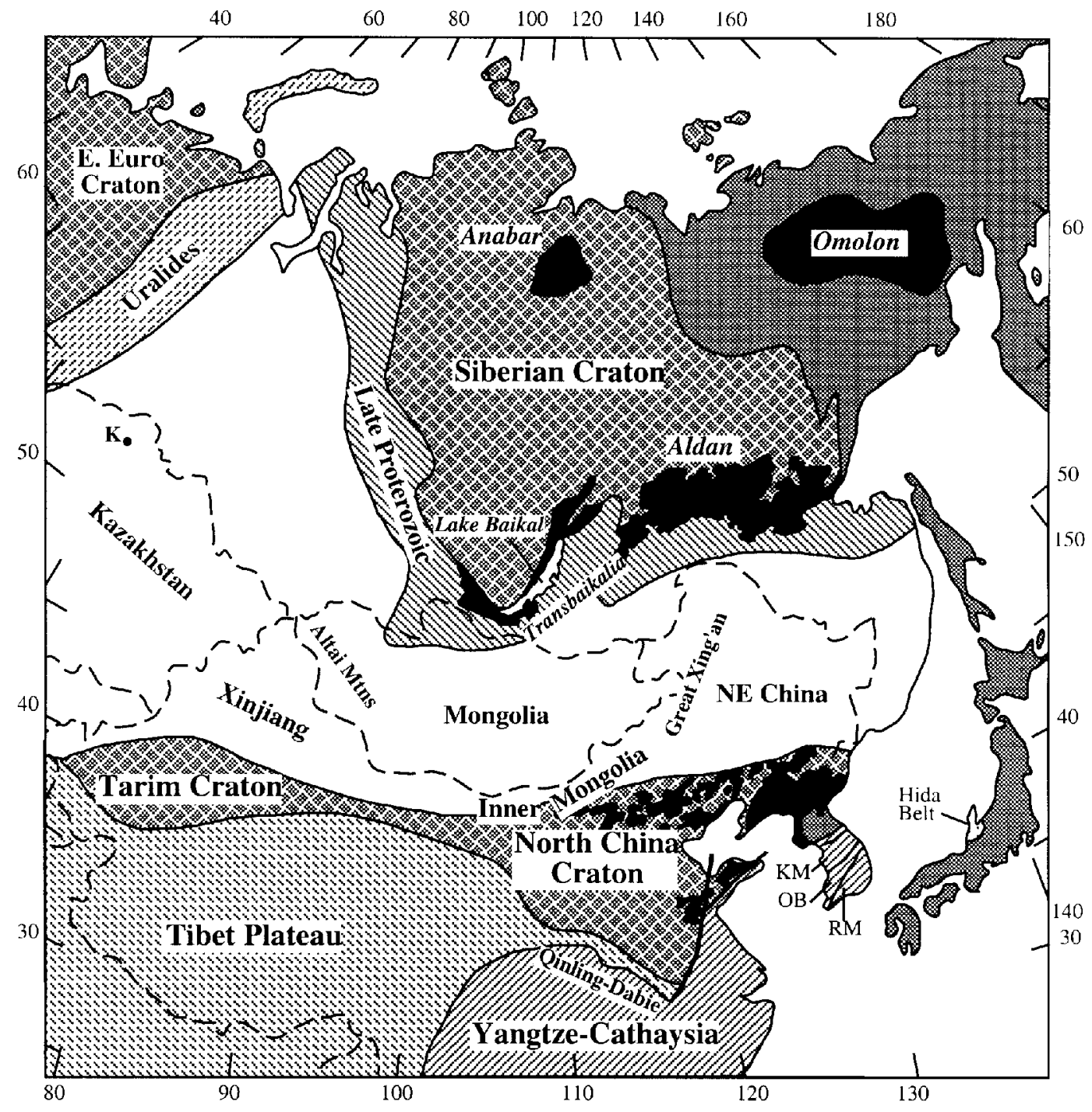

Figure 1 Simplified tectonic divisions of Asia. The Central Asian Orogenic Belt (CAOB), also known as the Altaid Tectonic Collage (Sengör et al., 1993), is situated between two major Precambrian cratons: Siberian in the north and North China-Tarim in the south. Black areas are exposed Archean to early Proterozoic rocks. Dark grey pattern on the right-hand side including Japanese islands represents Pacific foldbelts. The Hida Belt of Japan may belong tectonically to the CAOB. Abbreviations:

K = Kokchetav (in northern Kazakhstan); $K M=$ Kyonggi Massif, $O B=$ Ogcheon Belt, RM = Ryongnam Massif (all in Korea).

insignificant. This was earlier supported by $\mathrm{Nd}$ isotope studies of the granitoids from several intensely studied classic orogenic belts, such as the Caledonides, Hercynides, the Yangtze-Cathaysia of SE China, and the Himalayas. However, recent isotope investigations in western North American Cordilleras (DePaolo, 1981; Samson et al., 1989, 1995; Samson and Patchett, 1991; Whalen et al., 1996) and the Lachlan and New England Foldbelts of eastern Australia (McCulloch and Chappel, 1982; Hensel et al., 1985; Eberz et al., 1990; Collins, 1996, 1998) have revealed that a substantial proportion of the Phanerozoic crust is juvenile.

Central Asia is immense in size and its geology is poorly known outside of the former USSR and China. It is rich in mineral resources, which have been subject of numerous studies in the last forty years. In a synthesis of geologic data obtained in the former USSR and China, Sengör et al. (1993) hypothesized that nearly half of the gigantic Central Asian Orogenic Belt (which they termed the Altaid Tectonic Collage) was derived from the mantle by arc accretion. If this is true, the growth of the continental crust in the Phanerozoic would be much more significant than we have previously estimated from classic orogenic belts. That is, the Phanerozoic crust is no longer composed essentially of reworked Precambrian crust.

The purposes of this paper are: (1) to demonstrate the dominantly juvenile nature of the Phanerozoic granitoids from the CAOB using Sm-Nd isotopic data, and (2) to discuss the general implications on the global Phanerozoic crustal growth. We underline that the granitic rocks of the $\mathrm{CAOB}$ represent the most significant mass transfer from the mantle to the continental crust in the Phanerozoic.

\section{Lithological characters and emplacement periods of granites}

In Central Asia, very large volumes of granitic rocks of late Paleozoic to Mesozoic ages were emplaced during the formation of the Central Asian Orogenic Belt (CAOB). The CAOB, bounded by the Siberian and North China cratons (Figure 1), represents a complex evolution of Phanerozoic orogenic belts (Tang, 1990; Dobretsov et al., 1995) and it has also been termed Altaid Tectonic Collage (Sengör et al., 1993). According to Sengör, the Altaids was formed by successive accretion of arc complexes, accompanied by emplacement of immense volumes of granitic magmas. "Altaid Collage" may be better known to the western reader, but "CAOB" has been used for the past thirty years of research by the Russian and Chinese geologists, we therefore chose to use the latter simply to respect the tradition.

In this orogenic zone two gigantic belts of alkaline syenites and granites may be recognized: (1) a northern belt from central-northern Mongolia to Transbaikalia, and (2) a southern belt from Kazakhstan, Xinjiang, through southern Mongolia, Inner Mongolia to NE China (Figure 1). More than 350 distinct granitic plutons are exposed in northern Mongolia and Transbaikalia and occupy a total area $2500,000 \mathrm{~km}^{2}$ (Zanvilevich et al., 1995; Wickham et al., 1995, 1996). The available age data show five main stages of felsic magmatic activity in Transbaikalia (Zanvilevich et al., 1995; Wickham et 
al., 1995, 1996): (1) Ordovician-Silurian (450 Ma, U-Pb), (2) Devonian (375 Ma), (3) Early Permian (280 Ma ), (4) Late Perm ian (250 Ma), and (5) Triassic (220 Ma). Our ongoing study indicates that the magmatism extends to $100 \mathrm{Ma}$.

According to Kovalenko et al. (1995), these plutons include (1) the calc-alkaline series (tonalite-granodiorite-granite) of "Caledonian" ages in northern Mongolia and Transbaikalia (e.g., AngaraVitim batholith, Litvinovsky et al., 1992); (2) the "late Caledonian" calc-alkaline series in western Mongolia and the alkaline series in Tuva, Sayan, eastern Mongolian Altai, and vast areas in northern Mongolia and Transbaikalia; (3) the "Hercynian" (late Carboniferous to Permian) alkaline series in southern Mongolia and in northern Mongolia to Transbaikalia; Permian granitoids of the calc-alkaline series, represented by the vast Hangay batholith $\left(100,000 \mathrm{~km}^{2}\right)$ in west-central Mongolia; and (4) the early Mesozoic (2f0 Ma) granites of the calc-alkaline series and S-type granites in the MongolOkhotsk belt, plus the alkaline to peralkaline series in Transbaikalia. The lithologic types are composed mainly of alkaline and peralkaline granites, syenogranites, syenites and minor granodiorites.

In east central Kazakhstan, important mineralisations $(\mathrm{Au}, \mathrm{Cu}$, Mo-W, Sn, REE, Nb-Ta) are associated with a variety of igneous rocks including gabbros, diorites, granodiorites and granites (Heinhorst et al., 1999). These rocks were intruded in several episodes from 450 to $250 \mathrm{Ma}$. Heinhorst et al. (2000) considered these rocks to be formed in an active continental margin which developed from back-arc oceanic settings (for volcanic-hosted massive sulphide $\mathrm{Cu}-$ $\mathrm{Au}$ ore deposits) to subduction zone calc-alkaline magmatism (for $\mathrm{Cu}$ porphyries) with subsequent stages of differentiation (Mo porphyries) and finally to continental rifting magmatism (peralkaline REE-Zr-Nb deposits).

To the north in the Russian Altai, massive post-collisional alkaline granite intrusions were emplaced in Permian to Jurassic times. These rocks have been dated at 250 to $200 \mathrm{Ma}$ using zircon $\mathrm{U}-\mathrm{Pb}$ and $\mathrm{Rb}-\mathrm{Sr}$ isochron methods (Vladimirov et al., 1997).

In northern Xinjiang, granites of alkaline to calc-alkaline series appear to be dominant; most of these were emplaced in the period of 400-200 Ma but culminated around $300 \mathrm{Ma}$ (Hu et al., 1999a,b). Atype granites of the Ulungur River in northern Xinjiang were intruded at about $300 \mathrm{Ma}$ (Rb-Sr ages, Wang et al., 1994; Han et al., 1997) and those in Inner Mongolia were emplaced slightly later at ca. $280 \mathrm{Ma}$ (whole-rock Rb-Sr, Hong et al., 1995). In NE China, several hundred granitic bodies have been identified and constitute an area of $100,000 \mathrm{~km}^{2}$. The existing age data indicate four episodes of granitic intrusion (Fang, 1992; Jahn et al., 1999; Wu et al, 2000a): (1) late Permian (270-250 Ma), (2) late Triassic-early Jurassic (220-180 Ma), (3) middle Jurassic (170-150 Ma), and (4) Cretaceous (ca. $120 \mathrm{Ma}$ ). An apparent younging trend of granitic intrusions from the west to the east is observed within the southern part of the CAOB.

\section{Nd isotopic data for Phanerozoic granitoids—a survey}

Three principal types of diagrams will be presented : (a) initial $\mathrm{Nd}$ isotope composition $\varepsilon_{\mathrm{Nd}}(\mathrm{T})$ vs. intrusive ages; (b) $\varepsilon_{\mathrm{Nd}}(\mathrm{T})$ vs. depleted-mantle-based model age $\mathrm{T}_{\mathrm{DM}}$; and (c) $\mathrm{f}_{\mathrm{Sm} / \mathrm{Nd}}$ vs $\mathrm{T}_{\mathrm{DM}}$. For model ages, we assume a linear $\mathrm{Nd}$ isotope evolution for the depleted mantle $\varepsilon_{\mathrm{Nd}}=0$ at $4.56 \mathrm{Ga}$ to +10 at the present, but the choice of one- or two-stage model (DePaolo et al. 1991) is difficult as each model has its own uncertainty and inconvenience. In the single stage model, the main uncertainties lie on (1) Sm/Nd fractionation between granitic melts and their sources during partial melting, (2) $\mathrm{Sm} / \mathrm{Nd}$ fractionation during magma differentiation, and (3) mixing of melts or sources in petrogenetic processes (for more detailed discussion, see Jahn et al., 1990). Many peralkaline granitoids of Central Asia show highly fractionated REE patterns, sometimes with the tetrad effect (Masuda et al., 1987, Masuda and Akagi, 1990; Bau,
1996; Jahn et al., 1999) leading to enhanced Sm/Nd ratios and negative model ages. In this case, single-stage model ages are evidently not reasonable. On the other hand, the two-stage model assumes that all the sources for granites follow the same isotope evolution as the average continental crust, regardless of their true lithological characteristics. If this model is adopted, we shall observe that most granitoid data would form a linear array in the $\varepsilon_{\mathrm{Nd}}(\mathrm{T})$ vs $\mathrm{T}_{\mathrm{DM}}$ plots. Fortunately, this ambiguous problem can be partially "corrected" if the

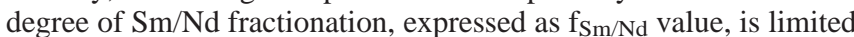
to the range of -0.2 to -0.6 , as shown later in Figure 4.

In the following, we first present isotope diagrams for the classic Phanerozoic orogenic belts in western Europe and in SE China and Korea, then demonstrate the contrasting isotopic features for the central Asian granitoids.

\section{Classic Phanerozoic orogenic belts}

\section{(a) European Caledonides and Hercynides}

In Figure 2 we summarize the available isotope data for the granitoids from the European Hercynides and Caledonides. The data of young Himalayan granites (ca. $20 \mathrm{Ma}$ ) are also shown for comparison, but their $\varepsilon_{\mathrm{Nd}}(\mathrm{T})$ values are not adjusted to a Palaeozoic age and their $\mathrm{T}_{\mathrm{DM}}$ were calculated using a two-stage model because most of them have $\mathrm{f}_{\mathrm{Sm} / \mathrm{Nd}}$ higher than -0.2 (Figure $2 \mathrm{~b}$ ). We note that almost all of the Hercynian (450 data points) and Caledonian granitoids (80) and all Himalayan leucogranites (29) are characterized by negative $\varepsilon_{\mathrm{Nd}}(\mathrm{T})$ values (Figure $2 \mathrm{a}$ ). This suggests that the granitoids were mainly generated from sources containing large proportions of recycled Precambrian crust. Most of the Hercynian granitoids with near-zero $\varepsilon_{\mathrm{Nd}}(\mathrm{T})$ values are the post-tectonic A-type granites from Corsica (Poitrasson et al., 1995). These rocks also have high $\mathrm{Sm} / \mathrm{Nd}$ ratios, leading to very high $\mathrm{T}_{\mathrm{DM}}$, up to $3800 \mathrm{Ma}$ (Figure $2 \mathrm{~b}$ ), but their mantle component is significantly higher than the rest as argued from the $\mathrm{Nd}$ isotope data. Figure $2 \mathrm{~b}$ shows that if $\mathrm{f}_{\mathrm{Sm} / \mathrm{Nd}}$ values are limited to $-0.4 \pm 0.2$, then the majority of $\mathrm{T}_{\mathrm{DM}}$ for the Hercynian and Caledonian granitoids would fall between 1000 to $2000 \mathrm{Ma}$. Note also that the Hercynian and Caledonian data sets cannot be distinguished as a whole.

\section{(b) SE China and S. Korea}

Cathaysia in the Yangtze Craton (Figure 1) is a major Phanerozoic orogenic belt in Asia. Like the CAOB, it is also characterized by voluminous Phanerozoic granitoids with rich mineralisations. Thus, a brief comparison of their isotopic signatures with those of the CAOB appears interesting for the understanding of their respective crustal development. Cathaysia has been considered as the easternmost part of the Tethyside orogen (Hsü et al., 1990; Sengör et al., 1993). Cathaysia and the CAOB are situated to the south and north of the Sino-Korean craton, respectively, and they exhibit very contrasting tectonic styles and crustal evolutions. Their principal characteristics and differences are summarized in Table 1. A-type granites also occur in Cathaysia (Xu et al., 1992), but their Nd isotopic signatures are generally "crustal" (Martin et al;, 1994; Charoy and Raimbault, 1994; Darbyshire and Sewell, 1997). Most granitic rocks in Cathaysia were produced by remelting of Proterozoic crustal sources; only very few granitic bodies in coastal Fujian and Taiwan have witnessed a greater contribution of the depleted mantle component in their magma genesis (Jahn et al., 1976, 1986, 1990; Huang et al., 1986; Lan et al., 1995b; Gilder et al., 1996; Chen and Jahn, 1998).

The Phanerozoic granitoids of SE China (Yangtze craton, Cathaysia and Taiwan) also show negative $\varepsilon_{\mathrm{Nd}}(\mathrm{T})$ values except a few cases (Figures 3a,b,c). Some Mesozoic granites from Dabieshan show the lowest $\varepsilon_{\mathrm{Nd}}(\mathrm{T})$ from -15 to -25, suggesting their derivation from a protolith of Archean to early Proterozoic age (Figure 3a). In the $\varepsilon_{\mathrm{Nd}}(\mathrm{T})$ vs initial ${ }^{87} \mathrm{Sr} /{ }^{86} \mathrm{Sr}$ diagram, the data indicate the dominance of both upper and lower crust in the generatin of granitic liquids. The mantle component is subordinate (Figure 3b). Single-stage model ages range from 1,000 to $2,500 \mathrm{Ma}$ for the majority of the 

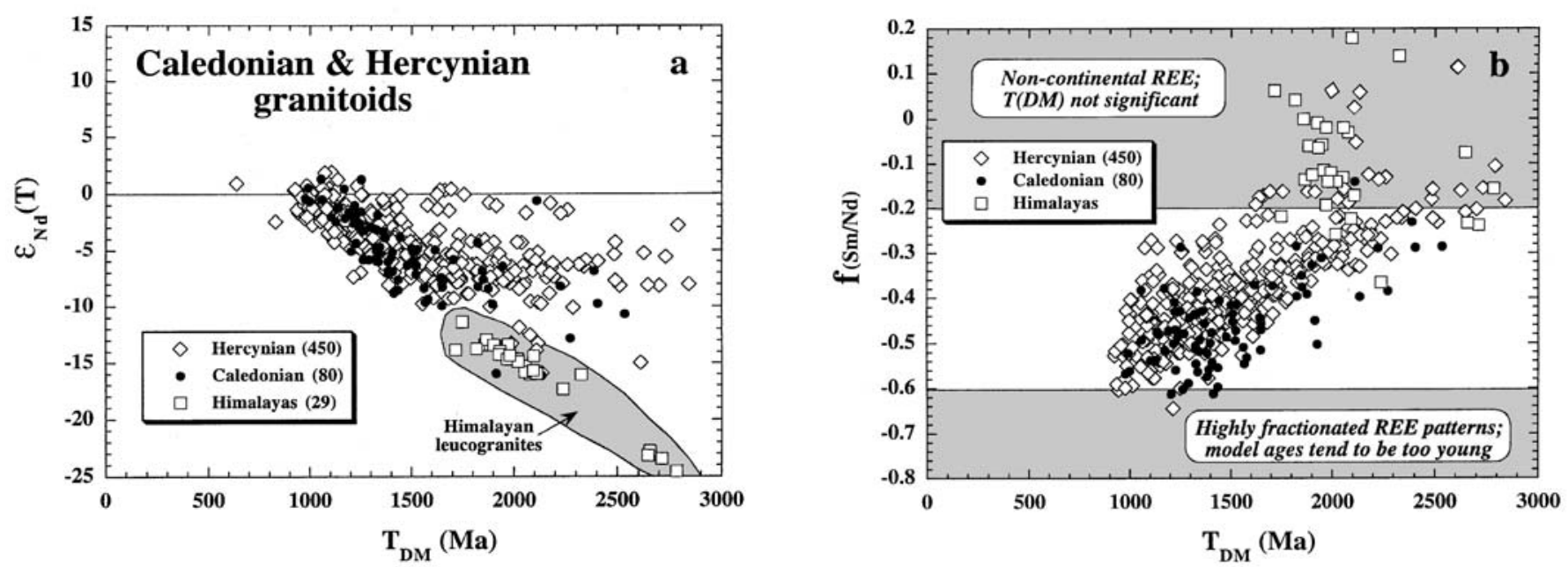

Figure 2 Isotope diagrams for granitoids from European Hercynides and Caledonides, and the Himalayas. Note that $T_{D M}$ for Himalayan leucogranites shown in (a) were calculated using a two-stage model because a large number of them have $f_{\text {Sm/Nd }}>-0.2$. Data sources : Caledonian Belt : Hamilton et al. (1980), Halliday (1984), Frost and O'Nions (1985), Dempsey et al. (1990), Skjerlie (1992); Herycinian Belt : Ben Othman et al. (1984), Bernard-Griffiths et al. (1985), Downes and Duthou (1988), Liew and Hofmann (1988), Liew et al. (1989), Pin and Duthou (1990), Turpin et al. (1990), Williamson et al. (1992); Cocherie et al. (1994), Darbyshire and Shepherd (1994); Dias and Leterrier (1994), Poitrasson et al. (1994, 1995), Moreno-Ventas et al. (1995), Siebel et al. (1995), Tommasini et al. (1995), Downes et al. (1997), Ajaji et al. (1998), Azevedo and Nolan (1998), Forster et al. (1999); Himalaya: Vidal et al. (1984), Deniel et al. (1987), Inger and Harris (1993), Gazis et al. (1998), Harrison et al. (1999).

granitoids (Figure 3c). However, Chen and Jahn (1998) showed that there is an oceanward younging of $\mathrm{T}_{\mathrm{DM}}$ and increase of $\varepsilon_{\mathrm{Nd}}(\mathrm{T})$ within the entire SE China.

With respect to the granitoids of SE China, the average late Paleozoic to Cretaceous granitoids of South Korea are characterized by even lower $\varepsilon_{\mathrm{Nd}}(\mathrm{T})$ values (Figures $3 \mathrm{~d}, \mathrm{e}, \mathrm{f}$ ) but comparable $\mathrm{T}_{\mathrm{DM}}$ model ages (Figure 3f). However, the basement gneisses and metasediments show very radiogenic initial $\mathrm{Sr}$ isotope ratios (up to $0.775)$ and very old Nd model ages (1,500-3,800 Ma). Furthermore, the $\mathrm{Sr}$ isotope data indicate that the granitoids had no direct genetic relationship with the metasediments or gneisses in the Ogcheon belt (Figure 3e).

Like in the European Caledonides and Hercynides, the granitoids of SE China and South Korea are dominated by the recycled continental crust. While the mantle component plays an important part in the generation of some Cretaceous granitoids in the coastal region of SE China and Taiwan (Jahn et al., 1990; Lan et al., 1995b; Chen and Jahn, 1998), it is totally absent in S. Korea. The overall picture indicates that there is a significant difference in the crustal development between SE China and S. Korea.

\section{Central Asian Orogenic Belt}

\section{(a) NE China \& Inner Mongolia}

In NE China, 2350 granitic bodies were intruded (mainly during the Mesozoic) in the Da Hinggan (or Great Khinggan), Xiao Hinggan (Lesser Khinggan) and Zhangguangcai Mountains. Some of the granites were emplaced within the domain of the Jiamusi Massif, a Precambrian microcontinental block whose metamorphic age

Table 1 Comparison of crustal evolution between the CAOB and Cathysia of SE China.

\begin{tabular}{|c|c|c|}
\hline & East-central Asia (Altaid) & SE China (Cathaysia) \\
\hline Type of orogen & Altaid (accretionary*) & Tethyside (collisional*) \\
\hline Characteristics & Immense Phanerozoic granitic intrusions & Immense Phanerozoic granitic intrusions \\
\hline Period of intrusion & 550 to $120 \mathrm{Ma}$ & $400(?)$ to $80 \mathrm{Ma}$ \\
\hline & $\Delta \mathrm{T} \approx 400 \mathrm{Ma}$ & $\Delta \mathrm{T} \approx 300 \mathrm{Ma}$ \\
\hline Total volume & $\approx 5.3 \mathrm{M} \mathrm{sq} \cdot \mathrm{km}^{* *}(\approx 11 \%$ total Asia $)$ & not estimated \\
\hline Granitic type & mainly I- and A-types & mainly S-type (I, A, M subordinate) \\
\hline $\begin{array}{l}\text { Crustal type } \\
\varepsilon N d(T)\end{array}$ & $\begin{array}{l}\text { Alkaline and peralkaline granites dominate } \\
\text { mainly juvenile } \\
\text { mostly positive }(+8 \text { to } 0)\end{array}$ & $\begin{array}{l}\text { CA granites dominate } \\
\text { mainly reworked } \\
\text { mostly negative }(-2 \text { to }-17)\end{array}$ \\
\hline Tectonics & $\begin{array}{l}\text { Assembly of numerous arc complexes; } \\
\text { intruded by vast granitic plutons and } \\
\text { covered in places by their volcanic eqv. } \\
\text { Plume activities? }\end{array}$ & $\begin{array}{l}\text { Assembly of ancient continental blocks; } \\
\text { vast granitic plutons formed by remelting } \\
\text { of old basement rocks }\end{array}$ \\
\hline Structure & $\begin{array}{l}\text { Nappe complexes rare or absent**; } \\
\text { suture zones broad }\end{array}$ & $\begin{array}{l}\text { Nappe complexes common; } \\
\text { suture zones narrow and elongate }\end{array}$ \\
\hline Basement rocks & $\begin{array}{l}\text { Precambrian basement rocks } \\
\text { comparatively rare** }\end{array}$ & Proterozoic basement dominates \\
\hline
\end{tabular}

* Terminology of Windley $(1993,1996) ; \quad * *$ According to Sengör et al. (1993) 

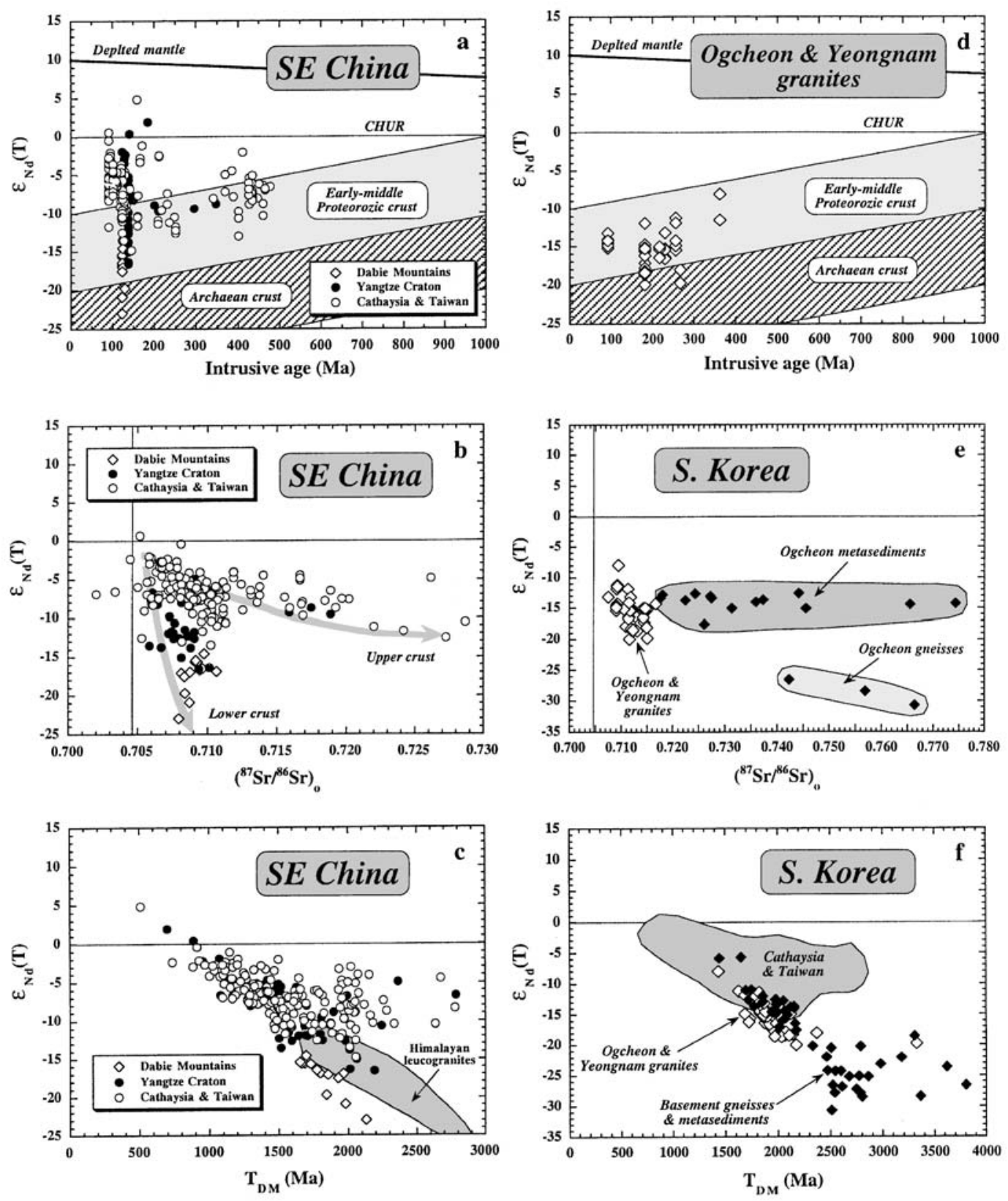

Figure 3 Isotope diagrams for granitoids from $S E$ China $(a, b, \&$ c) and $S$. Korea $(d, e, \&$ f $)$. Data sources : SE China : see references cited in Chen and Jahn (1998), South Korea Lan et al. (1995a), Cheong and Chang (1997), Lee et al. (1999).

has been precisely dated at 500 Ma by SHRIMP zircon analyses (Wilde et al., 1997, 2000). The granites are composed mainly of Itype and subordinated A-type granites (Wu et al., 2000a). They are covered by extensive Mesozoic and Tertiary acid volcanic rocks. Petrographic examination of deep drilled cores revealed that the Songliao Basin in central NE China is underlain by vast granitic rocks ( $\mathrm{Wu}$, unpublished). This suggests that the true volume of granitic rocks is much greater than what is observed in the present geologic map. Until now the tectonic setting for the emplacement of such immense distribution of granitic rocks in NE China is not resolved. It appears to have a connection with continental rifting but no relation with subduction zone processes.

In Inner Mongolia, several periods of granitic intrusions took place from Devonian to Jurassic times. Our samples came from a Paleozoic anorogenic A-type suite (280 Ma; Hong et al., 1995, 1996), an arc-related calc-alkaline magmatic belt composed of gabbroic diorite, quartz diorite, tonalite and granodiorite (SHRIMP zirocn age of $309 \pm 8 \mathrm{Ma}$ ) and a Mesozoic collision-type granitic suite of mainly adamellite with subordinate granodiorite and leucogranite ( $\mathrm{Rb}-\mathrm{Sr}$ age of $230 \pm 20 \mathrm{Ma}$; Chen et al., 2000).

The Nd-Sr isotope data including all derivative parameters (intrusive and model ages, $\mathrm{f}_{\mathrm{Sm} / \mathrm{Nd}}$ ) for the Phanerozoic granitic rocks from NE China, Inner Mongolia and the Hida belt of Japan are presented in Figure 4. In contrast to the European or SE China granites, the majority of the analyzed samples have positive $\varepsilon_{\mathrm{Nd}}(\mathrm{T})$ values, indicating their relatively juvenile character. Note that most of the samples with negative $\varepsilon_{\mathrm{Nd}}(\mathrm{T})$ values came from within the domain of the Precambrian Jiamusi Massif. Such a close relationship between the isotopic compositions of granitoids and the ages and nature of their intruded "basement" rocks is also demonstrated by the data from Xinjiang (see next section) and from the CAOB's northern belt of Mongolia-Transbaikalia (Kovalenko et al., 1996). This lowering of $\varepsilon_{\mathrm{Nd}}(\mathrm{T})$ values of granitic intrusions was most probably effected by contamination of old crustal rocks. 

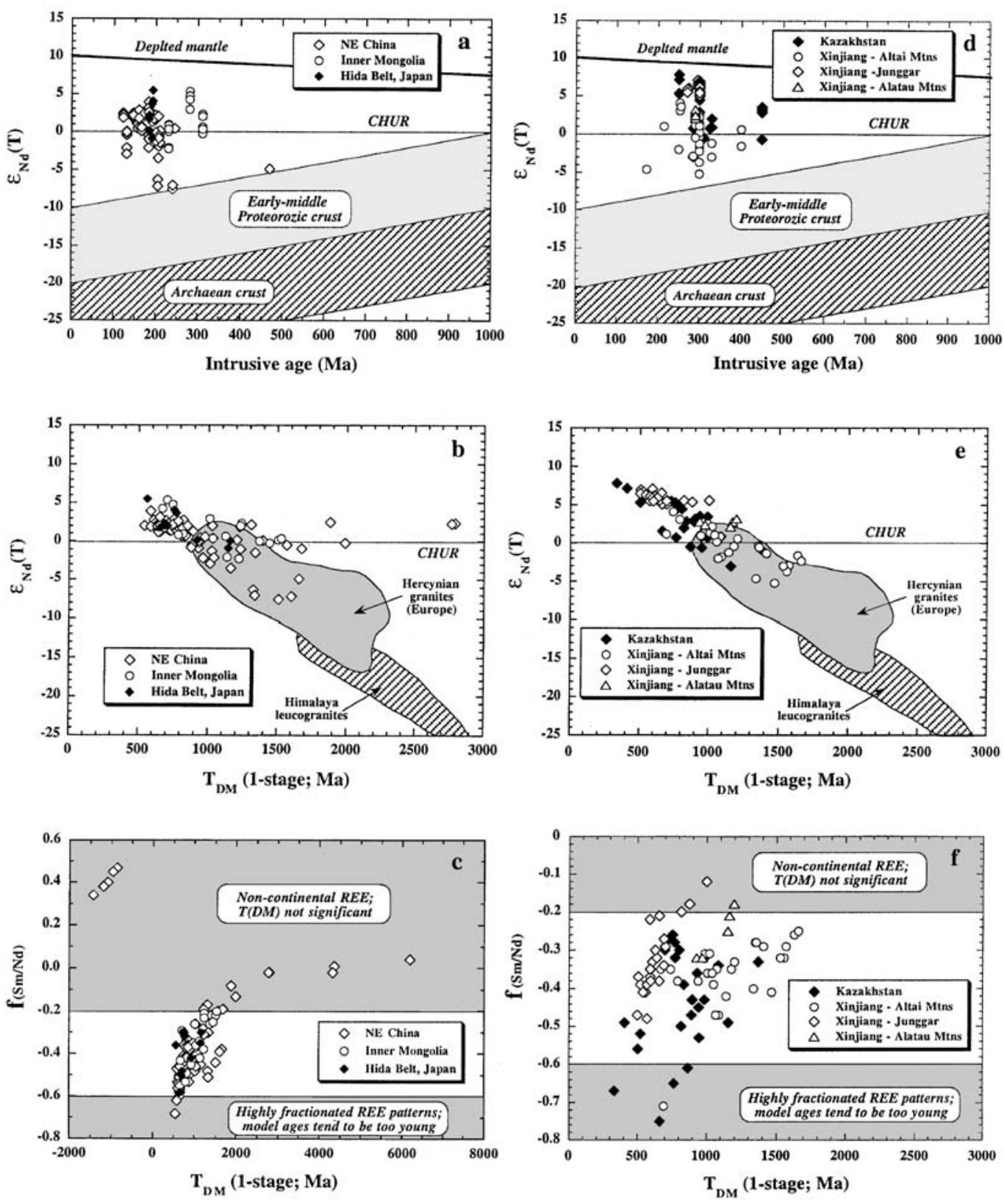

Figure 4 Isotope diagrams for granitoids from Kazakhstan, northern Xinjiang, NE China and Inner Mongolia. Data sources: NE China: Wu et al. (2000a, 2000b) and Jahn et al. (1999); Inner Mongolia: Jahn, unpublished; Hida belt: Arakawa and Shimura (1995) and Arakawa et al. (2000); Xinjiang: Zhao et al. (1993), Zhou et al. (1995), Jahn (unpublished); Kazakhstan: Heinhorst et al. (1999).

Figures $4 \mathrm{~b}$ and $4 \mathrm{c}$ show that they have a wide range of singlestage model ages. Aberrant model ages (negative or $\geq 4,000 \mathrm{Ma}$ ) are produced due to strong $\mathrm{Sm} / \mathrm{Nd}$ fractionation through crystallisation and magma-hydrothermal interaction leading to the tetrad effect of REE distribution (Masuda et al., 1987; Masuda and Akagi, 1990; Bau, 1996; Irber, 1999; Jahn et al., 1999). We therefore consider model ages interpretable only when $\mathrm{f}_{\mathrm{Sm} / \mathrm{Nd}}$ values are $-0.4 \pm 0.2$. Consequently, the granites of NE China and Inner Mongolia have young model ages ranging from 500 to $1200 \mathrm{Ma}$ except a few plutons emplaced in the Jiamusi Massif (Figures $4 \mathrm{~b}$ and $4 \mathrm{c}$ ). This is clearly distinguished from the granites of classic orogenic belts described above, and even more from the leucogranites of the Himalayas.

\section{(b) Northern Xinjiang-Altai and Junggar}

The geology of northern Xinjiang in NW China may be conveniently divided into five "terranes" (from north to south): Altai, East and West Junggar, and East and West Tianshan (Hu et al., 2000a). A brief summary of geological characteristics of these terranes was given by Hu et al. (2000a). The Altai terrane is a composite terrane consisting of Proterozoic gneiss complexes and Phanerozoic sedimentary cover and intrusions. The Junggar Basin is covered by Cenozoic desert and thick continental basin sediments $(\geq 10 \mathrm{~km})$ as old as Permian. Drilling records indicate little deformation within the basin, suggesting stable configuration of the basement at least since the Permian (Coleman, 1989). The nature of the Junggar basement has been much debated; some considered that the basin represents a microcontinent of Precambrian basement, whereas others regarded it as a trapped Paleozoic oceanic crust of various origins (Feng et al., 1989). Surrounding the Junggar Basin, numerous ophiolites are exposed in the East and West Junggar terranes as well as in its southern margin. These terranes can be appropriately referred to as "island arc assemblages" and no rocks of Precambrian ages have been documented. Coleman (1989) considered these terranes as 

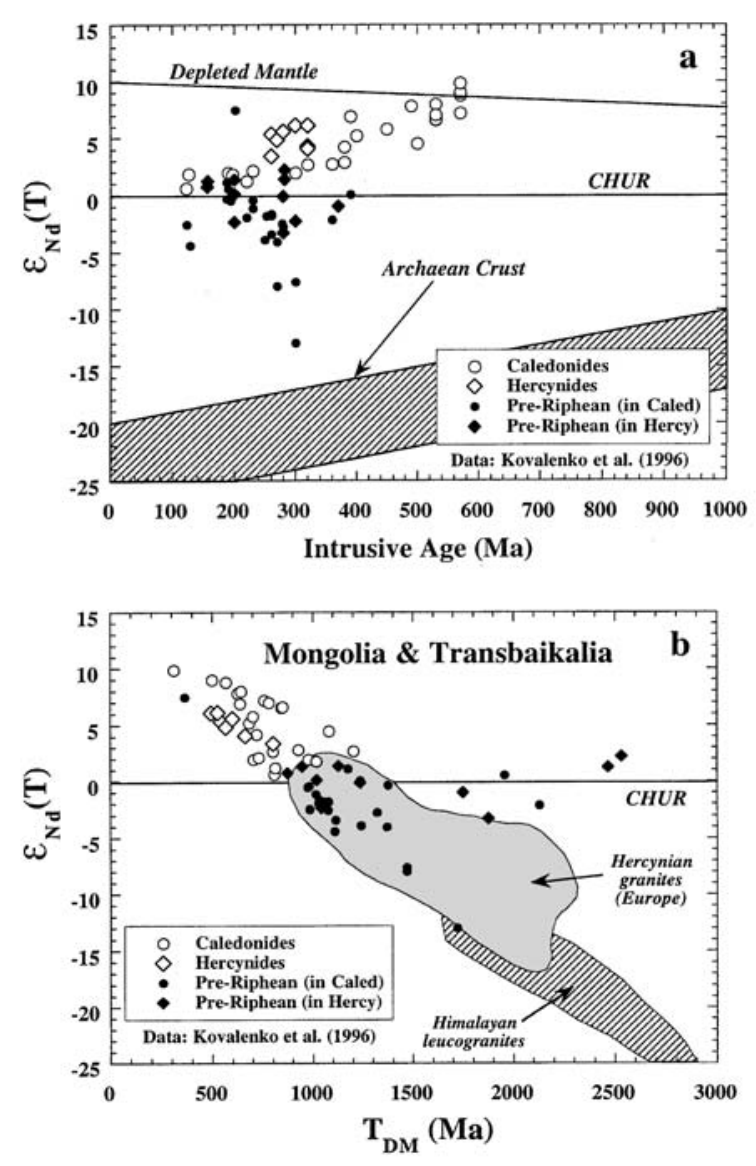

Figure 5 Isotope diagrams for granitoids from Mongolia and Transbaikalia. Data sources: Kovalenko et al. (1996). Granites intruded in "Caledonian and Hercynian" belts (open symbols) are characterized by positive $\varepsilon_{N d}(T)$ values, whereas those intruded in pre-Riphean basement (black symbols) have both positive and negative $\varepsilon_{N d}(T)$ values.

oceanic arc assemblages and compared them with those in the present western Pacific.

A variety of Phanerozoic granitoids occur throughout northen Xinjiang. As for the case of NE China, the majority of granitoids have positive $\varepsilon_{N d}(T)$ values (Figures $4 d$, e, f) which suggest very large proportions of the mantle component in the generation of these rocks. This is particularly true for the granitoids from the Junggar terranes (Zhao, 1993; Han et al., 1997) and Alatau Mtns (Zhou et al., 1995). On the other hand, granitoids emplaced in the Altai composite terrane tend to show a wider range of isotopic compositions (Figure $4 d)$. Granites of negative $\varepsilon_{\mathrm{Nd}}(\mathrm{T})$ values are most probably generated from a mixed source or due to contamination by Proterozoic gneisses during magma differentiation and emplacement.

Figures $4 \mathrm{e}$ and $4 \mathrm{f}$ show that the Junggar granites have very young model ages ranging from 300 to $1,000 \mathrm{Ma}$, whereas the granites from the Altai have more variable $\mathrm{T}_{\mathrm{DM}}$ from 700 to 1,700 Ma. A tight relationship between the isotopic compositions of granitoids and the nature of their basement rocks can be established. Hu et al. (2000a) concluded from their Sm-Nd isotope data that the basement rocks of Altai and Tianshan were largely produced in the Proterozoic, but that of Junggar seem to represent very young accreted terrane with little Precambrian history. The parallel manifestation of isotopic compositions and model ages between basement rocks and intrusive granites argue for the significant role of crustal contamination in the genesis of the Phanerozoic granitoids. A tectonic implica- tion is that the presence of old Precambrian microcontinents is important in the accretionary history in Central Asia.

\section{(c) East central Kazakhstan}

Heinhorst et al. (2000) undertook a comprehensive study of mineralisation in association with a variety of magmatic rocks in east-central Kazakhstan. Although the types of mineralisation ( $\mathrm{Au}$, $\mathrm{Cu}$, rare-metal, or REE) may be related to a particular magmatic suite or a lithological variety, most granitic rocks have positive $\varepsilon_{\mathrm{Nd}}(\mathrm{T})$ values (Figures $4 \mathrm{~d}$ and $4 \mathrm{e}$ ) irrespective of their compositions or rock types (Heinhorst et al., 2000). The granitoids were intruded in several episodes: 450 and $300 \mathrm{Ma}$ for magmatic suites with gold mineralisation, about $300 \mathrm{Ma}$ for granitoids of rare-metal mineralisation, and ca. $250 \mathrm{Ma}$ for A-type granites of REE mineralisation. Single stage model ages for all cases are between 400 to 1,400 Ma (Figure 4f).

\section{(d) Northern belt of the CAOB-Mongolia to Transbaikalia}

Kovalenko et al. (1996) delineated three isotope provinces ("Caledonian", "Hercynian", and pre-Riphean) which coincide with three tectonic zones of corresponding ages for the northern belt of the CAOB. We re-summarize their Nd isotopic data in Figure 5. Without exception, Phanerozoic granites emplaced into "Caledonian" and "Hercynian" tectonic zones have positive $\varepsilon_{\mathrm{Nd}}(\mathrm{T})$ values, suggesting their juvenile characteristics; whereas those intruded into the pre-Riphean basement show variable $\varepsilon_{\mathrm{Nd}}(\mathrm{T})$ from positive to negative values, indicating variable contributions of old Precambrian crust in the generation of granitic rocks (Figure 5a). Note that some late Neoproterozoic to early Paleozoic granites (600-500 Ma) have $\varepsilon_{\mathrm{Nd}}(\mathrm{T})$ values as high as +10 , indicating their derivation from an almost pure depleted mantle component.

Figure $5 \mathrm{~b}$ illustrates that the majority of the rocks emplaced in the Caledonian and Hercynian belts have Sm-Nd model ages younger than $1000 \mathrm{Ma}$, whereas those intruded in the Precambrian terranes have older $\mathrm{T}_{\mathrm{DM}}$ from ca. 900 to $2500 \mathrm{Ma}$. If the rocks with $\mathrm{fSm} / \mathrm{Nd}$ outside of the range $-0.4 \pm 0.2$ are excluded, then all granitoids would have $\mathrm{T}_{\mathrm{DM}}$ limited to $1500 \mathrm{Ma}$.

In addition to the $\mathrm{Nd}$ isotopic evidence, oxygen isotope analyses of alteration-resistant titanites from granites of Transbaikalia (Wickham et al., 1995, 1996) show a progressive decrease in $\delta^{18} \mathrm{O}$ of titanite (sphene) from $+6.5 \%$ in the earliest suite (450 Ma) to $+1.5 \%$ in the youngest suite $(220 \mathrm{Ma})$. This corresponds to a decrease in whole-rock $\delta^{18} \mathrm{O}$ from $+11 \%$ o to $+6 \%$ o. It appears that whereas the older magmas with higher $\delta^{18} \mathrm{O}$ values may have a crustal heritage, the younger magmas, particularly the A-type granites, became increasingly mantle-like in terms of their oxygen isotopic composition. This suggests that a series of important crustforming events were taking place in Central Asia in the late Phanerozoic.

\section{Discussion}

\section{Genesis of the Phanerozoic crust}

The above data for the southern belt of the CAOB-from Kazakhstan, northern Xinjiang, Inner Mongolia to NE China, covering a distance of nearly $5000 \mathrm{~km}$, indicate that most of the granitoids, despite of their highly differentiated nature and sometimes strong hydrothermal alteration leading to important mineralisations, possess a clear signature of high proportion of the mantle component in their petrogeneses. They are considered relatively juvenile and their massive intrusions suggest a significant addition of juvenile continental crust during the Phanerozoic. Likewise, the granitoids of the northern belt from central Mongolia to Transbaikalia have been extensively studied by Kovalenko and his associates, and a similar conclusion has been reached.

With regard to the massive generation of Phanerozoic juvenile crust, the best documented examples until now are those from the 


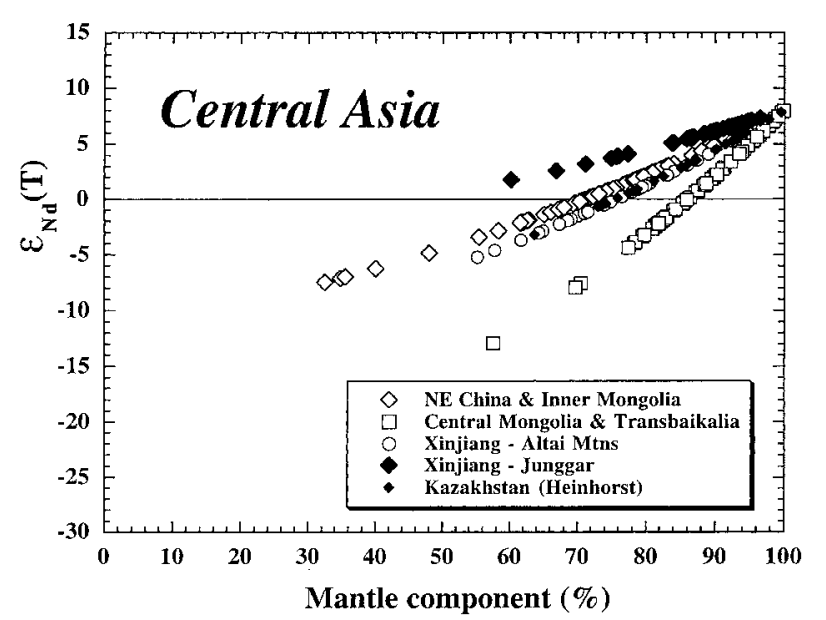

Figure 6 Estimate of proportions of the mantle or juvenile component in the generation of Central Asian granitoids. The equation used is :

$X^{m}=\left(\varepsilon^{c}-\varepsilon^{r}\right) N d_{c} /\left[\varepsilon\left(N d_{m}-N d_{c}\right)-\left(\varepsilon^{m} N d_{m}-\varepsilon^{c} N d_{c}\right)\right]$, where $X^{m}=\%$ mantle component (represented by basalt); $\varepsilon^{c}, \varepsilon^{c}, \varepsilon^{n}=N d$ isotope compositions of the crustal component, rock measured, and mantle component, respectively; $N d_{c}, N d_{m}=N d$ concentrations in the crustal and mantle components, respectively.

Parameters used: $\varepsilon^{n}=+8 ; \varepsilon^{c}=-12$ (NE China), -30 (Central Mongolia), -15 (Altai and Kazakhstan), -4 (Junggar); $N d_{m}=15$ ppm; $N d_{c}=25$ ppm.

Mesozoic Sierra Nevada and Peninsular Range batholiths in the western U.S. (DePaolo, 1981), the Canadian Cordillera (Samson et al., 1989; Samson and Patchett, 1991), the Appalachians (Whalen et al., 1996; Samson et al., 1995) and eastern Australia (McCulloch and Chappel, 1982; Hensel et al., 1985; Eberz et al., 1990; Collins, 1996, 1998). While a significant mantle contribution to the generation of the CAOB granitoids is indicated by the $\mathrm{Nd}$ isotopic evidence, the precise mechanisms for the growth and evolution of the Phanerozoic continental crust remain debatable. Sengör et al., (1993) suggested that subduction processes alone to be responsible for formation of the juvenile crust. Windley $(1993,1995)$ distinguishes two types of orogens: (1) collisional orogens, formed by the collision of two or more large continental blocks (e.g., Himalayas, Alps, Grenille, etc.), and (2) accretionary orogens, formed by the growth and amalgamation of island arcs, intervening accretionary prisms, etc. (e.g., Altaids, North American Cordillera, Andes, Birimian, Nubian-Arabian, etc.). A depleted mantle isotopic character is unusual for granitic rocks of collisional orogens worldwide, but are more commonly observed for those in accretionary orogens. High $\varepsilon_{\mathrm{Nd}}(\mathrm{T})$ values could reflect a direct contribution of mantle in subduction zones, but they could equally have no connection with subduction as well, as evidenced from the abundant A-type granites which are post-orogenic and not generated in subduction zones. Thus, subduction processes alone could not have been responsible for the formation of all the juvenile crust in the $\mathrm{CAOB}$.

\section{Implication for the origin of alkaline and peralkaline granitoids}

Although many plutons and batholiths of the CAOB belong to the calc-alkaline series and have differentiated I-type characteristics, the emplacement of voluminous granites of the alkaline and peralkaline series $(\mathrm{A} / \mathrm{NK} \leq 1$ and $\mathrm{A} / \mathrm{CNK} \leq 1$, with $\mathrm{A}, \mathrm{C}, \mathrm{N}, \mathrm{K}=$ molecular proportion of $\mathrm{Al}_{2} \mathrm{O}_{3}, \mathrm{CaO}, \mathrm{Na}_{2} \mathrm{O}$ and $\mathrm{K}_{2} \mathrm{O}$, respectively) is remarkable. Of these rocks, many are post-orogenic A-type granites $(\mathrm{A} / \mathrm{CNK} \leq 1)$, whose origin is still much debated, and it appears that no single petrogenetic model is applicable for all cases (Whalen et al., 1987; Eby, 1992). Mechanisms involving melting of crustal sources are favored from trace element geochemistry (e.g., Collins et al., 1982; Creaser et al., 1991; Cocherie et al., 1994; Poitrasson et al., 1995; Landenberger and Collins, 1996), whereas mantle sources are often advocated from isotopic constraints (Javoy and Weiss, 1987; Foland and Allen, 1991; Whalen et al., 1996; Han et al., 1997). However, this is not universally true, as many A-type granites are also known to have a crustal isotopic signature (Charoy and Raimbault, 1994; Darbyshire and Sewell, 1997). In most cases, rocks of mantle derivation have also been contaminated by crustal material to some extent. Models involving mixing of mantle-derived magmas and crustal components (assimilated crustal rocks or crust-derived magmas), followed by fractional crystallisation are becoming increasingly popular. It appears that the production of a huge amount of alkaline to peralkaline granites was initiated by extensive basalt underplating and accompanied by large-scale crustal extension. Consequently, intraplate magmatism was probably a significant process of continental growth in the Phanerozoic.

\section{Estimate of the proportions of juvenile crust}

The Phanerozoic era appears to be a period of significant continental growth. A detailed discussion of petrogenetic models for individual CAOB granites is beyond the scope of this paper, but it can be found in several related works (e.g., Litvinovsky et al., 1992; Kovalenko et al., 1995; Zanvilevich et al., 1995; Hong et al., 1995; Han et al., 1997; Litvinovsky and Zanvilevich, 1998; Wu et al., 2000a). The available trace element and Nd-Sr isotopic data of Atype granites from Xinjiang and Inner Mongolia, and differentiated I-type granites from NE China indicate that the mixing model is the most probable process and the dominance of mantle component over crustal material. A mixing calculation using a fixed depleted mantle $\left(\varepsilon_{\mathrm{Nd}}=+8\right)$ and variable crustal end-members suggest that the proportion of the mantle component (or \% juvenile crust) for positive $\varepsilon_{\mathrm{Nd}}(\mathrm{T})$ granites varies from 60 to $100 \%$ (Figure 6) depending on the compositions of the assumed crustal end-members, which are taken from the Jiamusi Massif for NE China $\left(\varepsilon_{\mathrm{Nd}}=-12\right.$, Jahn, unpublished), the Baidarik Block for Central Mongolia (-30, Kozakov et al., 1997), the basement gneisses for Altai (-15), and Junggar (-4), and the Kazak basement assumed to be the same as the Altai gneisses. This implies extensive mantle differentiation and rapid juvenile crustal addition during the Phanerozoic. However, significant proportions of recycled crust are visible in the granitoids emplaced in the Jiamusi Massif and Altai composite terranes, and Pre-Riphean zones in Mongolia and Transbaikalia.

For the entire Altaid Collage, Sengör et al. (1993) estimated that during the $350 \mathrm{Ma}$ of crustal evolution, a total area of about 2.5 million $\mathrm{km}^{2}$ of juvenile crust was added to Asia. This is translated into a growth rate of about $0.3 \mathrm{~km}^{3} / \mathrm{a}$. Combining this with the growth rate of the Canadian Cordillera (about $0.15 \mathrm{~km}^{3} / \mathrm{a}$, Samson et al., 1989; Samson and Patchett, 1991), the new rate would be at least $50 \%$ higher than the global growth rate of ca. $1.1 \mathrm{~km}^{3} /$ a deduced from arc magmatism only by Reymer and Schubert $(1984,1986)$. Consequently, the recent "discovery" of juvenile crust in several Phanerozoic orogenic belts, in particular the CAOB, may considerably change our views of the continental growth.

\section{Acknowledgments}

Fuyuan Wu acknowledges a financial support of the French Embassy in Beijing for a three-month visit at Rennes (1999) and the hospitality of Géosciences Rennes during his two-time stay in Rennes (1996 \& 1999). A post-doctoral fellowship from the Chinese Government allowed Bin Chen to conduct a year of research at Géosciences Rennes during October 1998 to September 1999. This research was supported by the INSU-CNRS through the Programme "Dynamique des Transferts Terrestres" (1997-1998) and "Interieur de la Terre" (1998-1999). This is INSU contribution No. 229. This 
is also a contribution to IGCP-420: Crustal Growth in the Phanerozoic: Evidence from East-Central Asia.

\section{References}

Ajaji,T., Weis, D., Giret, A. and Bouabdellah, M., 1998. Coeval potassic and sodic calc-alkaline series in the post-collisional Hercynian Tanncherfi intrusive complex, northeastern Morocco: Geochemical, isotopic and geochronological evidence. Lithos, 45, 371-393.

Azevedo, M. R. and Nolan, J., 1998. Hercynian late-post-tectonic granitic rocks from the Fornos de Algodres area (Northern Central Portugal). Lithos, 44, 1-20.

Arakawa, Y. and Shimura, T., 1995. Nd-Sr isotopic and geochemical characteristics of two contrasting types of calc-alkaline plutons in the Hida belt, Japan. Chem. Geol., 124, 217-232.

Arakawa, Y., Saito Y, Amakawa H., 2000. Crustal development of the Hida belt, Japan : Evidence from Nd-Sr isotopic and chemical characteristics of igneous and metamorphic rocks. Tectonophysics (in revision).

Armstrong, R. L., 1968. A model for $\mathrm{Sr}$ and $\mathrm{Pb}$ isotope evolution in a dynamic earth. Rev. Geophys., 6, 175-199.

Armstrong, R. L., 1981. Radiogenic isotopes: The case for crustal recycling on a near-steady state no-continental-growth Earth. Phil. Trans. Royal Soc. London, A 301, 443-472.

Armstrong, R. L., 1991. The persistent myth of crustal growth. Australia J. Earth Sci., 38, 613-630.

Bau, M., 1996. Controls on the fractionation of isovalent trace elements in magmatic and aqueous system: Evidence from $\mathrm{Y} / \mathrm{Ho}, \mathrm{Zr} / \mathrm{Hf}$, and lanthanide tetrad effect. Contrib. Mineral. Petrol., 123, 323-333.

Ben Othman, D., Fourcade, S. and Allegre, C. J., 1984. Recycling processes in granite-granodiorite complex genesis: the Querigut case studied by Nd-Sr isotope systematics. Earth Planet. Sci. Lett., 69, 290-300.

Bernard-Griffiths, J., Peucat, J.J., Sheppard, S. and Vidal, P., 1985. Petrogenesis of Hercynian leucogranites from the southern Armorican Massif: contribution of $\mathrm{REE}$ and isotopic ( $\mathrm{Sr}, \mathrm{Nd}, \mathrm{Pb}$, and $\mathrm{O}$ ) geochemical data to the study of source rock characteristics and ages. Earth Planet. Sci. Lett., 74, 235-250.

Charoy, B. and Raimbault, L., 1994. Zr-, Th- and REE-rich biotite differentiates in the A-type granites pluton of Suzhou (eastern China): the key role of fluorine. J. Petrology, 35, 919-962.

Chen, B., Jahn, B.M., Wilde, S., Xu, B., 1999. Two contrasting Paleozoic magmatic belts in northern Inner Mongolia, China : petrogenesis and tectonic implications. Tectonophysics (in press).

Chen, J.F. and Jahn, B.M., Crustal evolution of southeastern China : Nd and Sr isotopic evidence. Tectonophysics, $284: 101-133$.

Cheong, C. S. and Chang, H. W., 1997. Sr, Nd, and Pb isotope systematics of granitic rocks in the central Ogcheon belt, Korea. Geochim. J., 31: 17-36.

Cocherie, A., Rossi, Ph., Fouillac, A.M. and Vidal, Ph., 1994. Crust and mantle contributions to granite genesis: An example from the Variscan batholith of Corsica, France, studied by trace-element and Nd-Sr-O isotope systemetics. Chem. Geol., 115, 173-211.

Coleman, R.G., 1989. Continental growth of northwest China. Tectonics, 8 , 621-635.

Collins, W.J., Beams, S.D., White, A.J.R. and Chappell, B.W., 1982. Nature and origin of A-type granites with particular reference to southeastern Australia. Contrib. Mineral. Petrol., 80, 189-200.

Collins, W. J., 1996, Lachlan Fold Belt granitoids: products of three-component mixing. Transactions of the Royal Society of Edinburgh: Earth Sciences, v. 87, pp. 171-181.

Collins, W. J., 1998, Evaluation of petrogenetic models for Lachlan Fold Belt granitoids: implications for crustal architecture and tectonic models. Australian Journal of Earth Sciences, v. 45, pp. 483-500.

Creaser, R.A., Price, R.C. and Wormald, R.J., 1991. A-type granites revisited: assessment of a residual-source model. Geology, 19, 163-166.

Darbyshire, D.P.F., Sewell, R.J., 1997. Nd and Sr isotope geochemistry of plutonic rocks from Hong Kong: implications for granite petrogenesis, regional structure and crustal evolution. Chem. Geol., 143, 81-93.

Darbyshire, D. P. F. and Shepherd, T. J., 1994. Nd and Sr isotope constraints on the origin of the Cornubian batholith, SW England. J. Geol. Soc. London, 151, 795-802.

Dempsey, C. S., Halliday, A. N. and Meighan, I. G., 1990. Combined Sm-Nd and $\mathrm{Rb}-\mathrm{Sr}$ isotope systematics in the Donegal granitoids and their petrogenic implications. Geol. Mag., 127, 75-80.

Deniel, C., Vidal, P., Fernandez, A., Le Fort, P. and Peucat, J. J., 1987. Isotopic study of the manaslu granite (Himalaya, Nepal): Inferences on the age and source of Himalayan leucogranites. Contrib. Mineral. Petrol., 96, 78-92.
DePaolo, D.J., 1981. A neodynium and strontium isotopic study of the Mesozoic calc-alkaline granitic batholiths of the Sirra Nevada and Peninsular Ranges, California. J. Geophys. Res., 86, 10470-10488.

DePaolo, D. J., Linn, A. M., \& Schubert, G. (1991). The continental crustal age distribution: Methods of deteriming mantle separation ages from Sm$\mathrm{Nd}$ isotopic data and application to the Southeastern United States. J. Geophys. Res., 96, 2071-2088.

Dias, G. and Leterrier, J., 1994. The genesis of felsic-mafic plutonic associations: A Sr and Nd isotopic study of the Hercynian Braga granitoid Massif (Northern Portugal). Lithos, 32, 207-223.

Dobretsov, N. L., Berzin, N. A. and Buslov, M. M., 1995. Opening and tectonic evolution of the Paleo-Asian ocean. Inter. Geol. Rev., 37, 335-360.

Downes, H. and Duthou, J. L., 1988. Isotopic and trace-element arguments for the lower-crustal origin of Hercynian granitoids and Pre-Hercynian orthogeneisses, Massif Central (France). Chem. Geol., 68, 291-308.

Downes, H., Shaw, A., Williamson, B.J. and Thirlwall, M.F., 1997. Sr, Nd and $\mathrm{Pb}$ isotope geochemistry of the Hercynian granodiorites and monzogranites, Massif Central, France. Chem. Geol., 136, 99-122.

Eby, G.N., 1992. Chemical subdivision of the A-type granitoids: petrogenetic and tectonic implications. Geology, 20, 641-644.

Fang, W.C., 1992. Granitoids and mineralisation in Jilin Province. Jilin Sci. Tech. Publ. House, Jilin, China, 271 pp.

Feng, Y., Coleman, R. G. and Tilton, G., 1989. Tectonic evolution of the West Junggar region, Xinjiang, China. Tectonics, 8, 729-752.

Foland, K.A. and Allen, J.C., 1991. Magma sources for Mesozoic anorogenic granites of the White Mountain magma series, New England, U.S.A. Contrib. Mineral. Petrol., 109, 195-211.

Forster, H. -J., Tischendorf, G., Trumbull, R. B. and Gottesmann, B., 1999. Late-collisional granites in the Variscan Erzgebirge, Germany. J. Petrol., 40, 1613-1645.

Frost, C. D. and O'Nions, R. K., 1985. Caledonian magma genesis and crustal recycling. J. Petrol., 26, 515-544.

Gazis, C. A., Blum, J. D., Chamberlain, C. P. and Poage, M., 1998. Isotope systematics of granites and gneisses of the Nanga Parbat Massif, Pakistan Himalaya. J. Am. Sci., 298, 673-698.

Gilder, S.A., Gill, J., Coe, R.S., Zhao, X., Liu, Z., Wang, G., Yuan, K., Liu, W., Kuang, G. and Wu, H., 1996. Isotopic and paleomagmatic constraints on the Mesozoic tectonic evolution of south China. J. Geophys. Res., 101, 16137-16154.

Halliday, A. N., 1984. Coupled Sm-Nd and U-Pb systematics in late Caledonian granites and the basement under northern Britain. Nature, 307, 229-233.

Hamilton, P. J., O'Nions, R. K. and Pankhurst, R. J., 1980. Isotopic evidence for the provenance of some Caledonian granites. Nature, 287, 279-284.

Han, B. F., Wang, S. G., Jahn, B. M., Hong, D. W., Kagami, H. and Sun, Y. L., 1997. Depleted-mantle magma source for the Ulungur River A-type granites from north Xinjiang, China: geochemistry and $\mathrm{Nd}-\mathrm{Sr}$ isotopic evidence, and implication for Phanerozoic crustal growth. Chem Geol., 138, 135-159.

Harrison, T. M., Grove, M., McKeegan, K. D., Coath, C. D., Lovera, O. M. and Le Fort, P., 1999. Origin and episodic emplacement of the Manaslu intrusive complex, Central Himalaya. J. Petrol., 40, 3-19.

Heinhorst, J., Lehmann, B., Ermolov, P., Serykh, V., Zhurutin, S., 2000. Paleozoic crustal growth and metallogeny of Central Asia : evidence from magmatic-hydrothermal ore systems of Central Kazakhstan. Tectonophysics (in press).

Hensel, H.-D., McCulloch, M.T. and Chappell, B.W., 1985, The New England Batholith: Constraints on its derivation from $\mathrm{Nd}$ and $\mathrm{Sr}$ isotopic studies of granitoids and country rocks: Geochimica Cosmochimica Acta, 49, 369-384.

Hong, D.W., Huang, H.Z., Xiao, Y.J., Xu, H.M. and Jin, M.Y., 1995. Permian alkaline granites in central Inner Mongolia and their geodynamic significance. Acta Geologica Sinica, 8, 27-39.

Hong, D.W., Wang, S.G., Han, B.F. and Jin, M.Y., 1996. Post-orogenic alkaline granites from China and comparisons with anorogenic alkaline granites elsewhere. J. SE Asian Earth Sci., 13, 13-27.

Hsü, K.J., Li, J.L., Chen, H.H., Wang, Q.C., Sun, S. and Sengör, A.M.C., 1990. Tectonics of South China: key to understanding west Pacific geology. Tectonophysics, 183, 9-39. 1990.

Hu, A.Q., Jahn, B.M., Zhang, G., Zhang, Q., 2000a. Crustal evolution and Phanerozoic crustal growth in Northern Xinjiang: Nd-Sr isotopic evidence. Part I: Isotopic characterization of basement rocks. (in preparation).

Hu, A.Q., Jahn, B.M., Zhang, G., Zhang, Q., 2000b. Crustal evolution and Phanerozoic crustal growth in Northern Xinjiang: Nd-Sr isotopic evidence. Part II: Phanerozoic granite intrusions (in preparation). 
Huang, X., Sun, S.H., DePaolo, D.J. and Wu, K.L., 1986. Nd-Sr isotope study of Cretaceous magmatic rocks from Fujian province. Acta Petrol. Sinica, 2, 50-63.

Irber, W., 1999. The lanthanide tetrad effect and its correlation with $\mathrm{K} / \mathrm{Rb}$, $\mathrm{Eu} / \mathrm{Eu} *, \mathrm{Sr} / \mathrm{Eu}, \mathrm{Y} / \mathrm{Ho}$, and $\mathrm{Zr} / \mathrm{Hf}$ of evolving peraluminous granite suites. Geochim. Cosmochim. Acta, 63, 489-508.

Inger, S. and Harris, N., 1993. Geochemical constraints on leucogranite magmatism in the Langtang Valley, Nepal Himalaya. J. Petrol., 34, 345368.

Jahn, B.M., Chen, P.Y. and Yen, T.P., 1976. Rb-Sr ages of granitic rocks in southeastern China and their tectonic significance. Bull. Geol. Soc. Am., 86, 763-776.

Jahn, B.M., Martineau, F., Peucat, J.J. and Cornichet, J., 1986. Geochronology of the Tananao Schist complex, Taiwan, and its regional tectonic significance. Tectonophysics, 125, 103-124.

Jahn, B.M., Zhou, X.H. and Li, J.L., 1990. Formation and tectonic evolution of southeastern China and Taiwan: Isotopic and geochemical constraints. Tectonophysics, 183, 145-160.

Jahn B. M., Wu F. Y., Capdevila, R., Wang, Y. X. and Zhao, Z. H., 1999, Highly evolved juvenile granites with tetrad REE patterns: The Woduhe and Baerzhe granites from the Great Xing'an (Khingan) Mountain in NE China. Abstract of IGCP420 2nd Workshop in Ulaanbaator, in G. Bardach and B. M. Jahn (eds.), Géosciences Rennes, Hors Série No. 2, pp. 43-46.

Jahn, B. M., Wu, F. Y. and Hong D. W., 2000, Important crustal growth in the Phanerozoic: Isotopic evidence of granitoids from East-central Asia. Gopalan festchrift volume, Proc. Indian Acad. Sci. (earth Planet.Sci.), v. 109 , pp. 5-20.

Javoy, M. and Weiss, D., 1987. Oxygen isotopic composition of alkaline anorogenic granites as a clue to their origin: the problem of crustal oxygen. Earth Planet. Sci. Lett., 84, 415-422.

Kovalenko, V., Yarmolyuk, V., and Bogatikov, O., 1995. Magmatism, geodynamics, and metallogeny of Central Asia. Miko Commercial Herald Publishers, Moscow. 272 pp.

Kovalenko, V.I., Yarmolyuk, V.V., Kovach, V.P., Kotov, A.B., Kozakov, I.K., Sal'nikova, E.B., 1996. Sources of Phanerozoic granitoids in Central Asia: Sm-Nd isotope data. Geochem. Int'1., 34, 628-640.

Kozakov, I.K., Kotov, A.B., Kovach, V.P. and Sal'nikova, E.B., 1997, Crustal growth in the geological evolution of the Baidarik block, central Mongolia: Evidence from Sm-Nd isotopic systematics.: Petrology, 5(3), 201-207 (Translated from Petrologiya, 5, 227-235).

Lan, C, Y., Lee, T., Zhou, X. H. and Kwon, S. T., 1995a. Nd isotopic study of Precambrian basement of South Korea: Evidence for early Archean crust? Geology, 23: 249-252.

Lan, C.Y., Lee Typhoon, Jahn, B.M., Yui, T.F., 1995b. Taiwan as a witness of repeated mantle inputs - Sr-Nd-O isotopic geochemistry of Taiwan granitoids and metapelites. Chem. Geol., 124 : 287-303.

Landenberger, B. and Collins, W.J., 1996. Derivation of A-type granites from a dehydrated charnocktic lower crust: evidence from the Chaelund Complex, eastern Australia. J. Petrology, 37, 145-170.

Lee, J. I., Jwa, Y. J., Park, C. H., Lee, M. J., Moutte, J. and Kagami, H., 1999. $\mathrm{Sr}$ and $\mathrm{Nd}$ isotopic compositions of late Plaeozoic Youngju and Andong granites in the northeastern yeongnam massif, Korea. Geochem. J., 33 153-165.

Liew, T. C. And Hofmann, A. W., 1988. Precambrian crustal components, plutonic association, plate environment of the Hercynian fold belt of central Europe: Indications from a $\mathrm{Nd}$ and $\mathrm{Sr}$ isotopic study. Contrib. Mineral. Petrol., 98, 129-138.

Liew, T. C., Finger, F. and Hock, V., 1989. The Moldanubian granitoid plutons of Austria: Chemical and isotopic studies bearing on their environmental setting. Chem. Geol., 76, 41-55.

Litvinovsky, B.A., Zanvilevich, A.N., Alakshin, A.M., and Podladchikov, Yu., 1992. The Angara-Vitim batholith-the largest granitoid pluton. Novosibirsk, Nauka, 141 pp.

Litvinovsky, B.A. and Zanvilevich, A.N., 1998, Compositional trends of silicic and mafic magmas formed in the course of evolution of the Mongolian-Transbaikalian mobile belt: Russian Geol. \& Geophys., 39: 155-180.

Martin, H., Bonin, B., Capdevila, R., Jahn, B.M., Lamayre, J. and Wang, Y., 1994. The Kuiqi peralkaline granitic complex (SE China): petrology and geochemistry. J. Petrology, 35, 983-1015.

Masuda, A. and Akagi, T., 1990. Lanthanide tetrad effect observed in leucogranites from China. Geochim. J., 23: 245-253.

Masuda, A., Kawakami, O., Dohmoto, Y. and Takenaka, T., 1987. Lanthanide tetrad effects in nature: two mutually opposite types, W and $\mathrm{M}$ Geochum. J., 21, 119-124.

McCulloch, M.T. and Chappell, B.W., 1982, Nd isotopic characteristics of Sand I-type granites: Earth and Planetary Science Letters, 58:51-64.
Moorbath, S., 1978. Age and isotopic evidence for the evolution of continental crust. Philosophical Transactions of the Royal Society of London, 288, 401-413.

Moreno-Ventas, I., Rogers, G. and Castro, A., 1995. The role of hybridization in the genesis of Hercynian granitoids in the Gredos Massif, Spain Inferences from Sr-Nd isotopes. Contrib. Mineral. Petrol., 120, 137-149.

Pin, C. and Duthou, J. L., 1990. Sources of Hercynian granitoids from the French Massif Central: Inferences from $\mathrm{Nd}$ isotopies and consequences for crustal evolution. Chem. Geol., 83, 281-296.

Poitrasson, F., Pin, C., Duthou, J. L. and Platevoet,, B., 1994. Aluminous subsolvus anorogenic granite genesis in the light of $\mathrm{Nd}$ isotopic heterogeneity. Chem. Geol., 112, 199-219.

Poitrasson, F., Duthou, J.L. and Pin, C., 1995. The relationship between petrology and $\mathrm{Nd}$ isotopes as evidence for contrasting anorogenic granite genesis: example of the Corsican Province (SE France). J. Petrol., 36, 1251-1274.

Reymer, A. and Schubert, G., 1984. Phanerozoic addition rates to the continental crust and crustal growth. Tectonics, 3, 63-77.

Reymer, A. and Schubert, G., 1986. Rapid growth of some major segments of continental crust. Geology, 14, 299-302.

Samson, S.D. and Patchett, P.J., 1991. The Canadian Cordillera as a modern analogue of Proterozoic crustal growth. Aust. Jour. Earth Sci., 38, 595611

Samson, S.D., McClelland, W.C., Patchett, P.J., Gehrels, G.E., Anderson, R.G., 1989. Evidence from neodymium isotopes for mantle contributions to Phanerozoic crustal genesis in the Canadian Cordillera. Nature, 337, 705-709.

Samson, S. D., Hibbard, J. P. and Wortman, G. L., 1995. Nd isotopic evidence for juvenile crust in the Carolina terrane, southern Appalachians. Contrib. Mineral. Petrol., 121: 171-184.

Sengör, A.M.C., Natal'in, B.A. and Burtman, V.S., 1993. Evolution of the Altaid tectonic collage and Paleozoic crustal growth in Eurasia. Nature, 364, 299-307, 1993.

Siebel, W., Hohndorf, A. and Wendt, I., 1995. Origin of late Variscan granitoids from NE Bavaria, Germany, exemplified by REE and $\mathrm{Nd}$ isotope systematics. Chem. Geol., 125, 249-270.

Skjerlie, K.P., 1992. Petrogenesis and significance of late Caledonian granitoid magmatism in western Norway. Contrib. Mineral. Petrol., 110, 473 487.

Stein, M. and Hofmann, A.W., 1994. Mantle plumes and episodic crustal growth. Nature, 372, 63-68.

Tang, K. D., 1990. Tectonic development of Palaeozoic fold belts at the north margin of the Sino-Korean craton. Tectonics, 9: 249-260.

Taylor, S.R. and McLennan, S.M., 1985. The continental crust: its composition and evolution. Blackwell, 312 pp. 1985.

Taylor, S.R. and McLennan, S.M., 1995. The geochemical evolution of the continental crust. Rev. Geophisics, 33, 241-265.

Tommasini, S., Poli, G. and Halliday, A. N., 1995. The role of sediment subduction and crustal growth in Hercynian plutonism: Isotopic and trace element evidence from the Sardinia-Corsica batholith. J. Petrol., 36, 1305-1332.

Turpin, L., Cuney, M., Friedrich, M., Bouchez, J-L. and Aubertin, M., 1990. Meta-igneous origin of Hercynian peraluminous granites in N. W. French Massif Central: Implications for crustal history reconstructions. Contrib. Mineral. Petrol., 104, 163-172.

Vidal, P., Bernard-Griffiths, J., Cocherie, A., Le Fort, P., Peucat, J.J. and Sheppard, S., 1984. Geochemical comparison between Himalayan and Hercynian leucogranites. Phys. Earth Planet. Interiors, 35, 179-190.

Vladimirov, A.G., Ponomareva, A.P., Shokalskii, S.P., Khalilov, V.A., Kostitsyn, Y.A., Ponomarchuk, V.A., Rudnev, S.N., Vystavnoi, S.A., Kruk, N.N., Tittov, A.V., 1997. Late Paleozoic-Early Mesozoic granitoid magmatism in Altai. Russian Geol. \& Geophys., 38, 755-770.

Wang, S. G., Han, B. F., Hong, D. W., Xu, B. L. and Sun, Y. L., 1994. Geochemistry and tectonic significance of alkali granites along Ulungur River, Xinjiang (in Chinese with English abstract). Scientia Geologica Sinica, 29, 373-383.

Whalen, J.B., Currie, K.L. and Chappell, B.W., 1987. A-type granites: geochemical characteristics, discrimination and petrogenesis. Contrib. Mineral. Petrol., 95, 407-419.

Whalen, J.B., Jenner, G.A., Longstaff, F.J., Robert, F. and Galiépy, C., 1996. Geochemical and isotopic $(\mathrm{O}, \mathrm{Nd}, \mathrm{Pb}$ and $\mathrm{Sr})$ constraints on A-type granite petrogenesis based on the Topsails igneous suite, Newfoundland Appalachians. J. Petrology, 37, 1463-1489.

Wickham, S. M., Litvinovsky, B. A., Zanvilevich, A. N. and Bindeman, I. N. 1995. Geochemical evolution of Phanerozoic magmatism in Transbaikalia, East Asia: a key constraint on the origin of K-rich silicic mag- 
mas and the process of cratonization. J. Geophys. Res., 100, 1564115654 .

Wickham, S. M., A.D. Alberts, Zanvilevich, A. N., Litvinovsky, B. A., Bindeman, I. N. and Schuble, E.A., 1996. A stable isotope study of anorogenic magmatism in East Central Asia. J. Petrology, 37, 1063-1095.

Wilde, S. A., Dorsett-Bain, H. L. and Liu, J. L.,. 1997. The identification of a Late Pan-African granulite facies event in Northeastern China: SHRIMP $\mathrm{U}-\mathrm{Pb}$ zircon dating of the MashanGroup at Liu Mao, Heilongjiang Province, China. Proceedings of the 30th IGC: Precambrian Geol. Metamorphic Petrol., 17, 59-74.

Wilde, S.A., Zhang, X.Z., Wu, F.Y., 2000. Extension of a newly-identified 500 Ma metamorphic terrain in NE China: further U-Pb SHRIMP dating of the Mashan Complex, Heilongjiang Province, China. Tectonophysics (in revision).

Williamson, B. J., Downes, H. and Thirlwall, M. F., 1992. The relationship between crustal magmatic underplating and granite genesis: An example from the Velay granite complex, Massif Central, France. Trans. Royal Soc. Edinburg: Earth Sci., 83, 235-245.

Windley, B., 1993. Proterozoic anorogenic magmatism and its orogenic connections. J. Geol. Soc. London, 150, 39-50.

Windley, B., 1995. The Evolving Continent, 3rd edition. John Wiley \& Sons, Chichester, 526 pp.

Wu, F.Y., Jahn, B.M., Lin, Q., Ge, W.C. and Sun, D.Y., 2000a. Highly fractionated I-type granites from NE China: geochemistry, petrogenesis and implications for continental growth. (to be submitted to J. Petrology).

Wu, F. Y., Jahn, B. M. and Sun D. Y., 2000b. Phanerozoic crustal growth: Sr$\mathrm{Nd}$ isotopic evidence from the granites in northeastern China (to be submitted to Tectonophysics).

Xu, K.Q., Zhu, J.C., Liu, C.S., Shen, W.Z. and Xu, S.J., 1992. Genetic series and material sources of granitoids in South China. In: G.Z. Tu, K.Q. Xu and Y.Z. Qiu (eds.), Petrogenesis and Mineralisation of Granitoids. Science Press, Beijing, 3-22.

Zanvilevich, A. N., Litvinovsky, B. A. and Wickham, S. M., 1995. Genesis of alkaline and peralkaline syenite-granite series: the Kharitonovo pluton (Transbaikalia, Russia), J. Geol., 103, 127-145.

Zhao, Z.H., 1993. REE and O-Pb-Sr-Nd isotopic compositions and petrogenesis of the Altai granitoids. In: New Development of Solid Earth Science in Northern Xinjiang. Science Publishing Co., Beijing, 239-266.

Zhou, T.X., Chen, J.F., Chen, D.G. and Li, X.M., 1995. Geochemical characteristics and genesis of granitoids from Alataw Mountain, Xinjiang, China. Geochimica, 24, 32-42 (in Chinese with English abstract).
Bor-ming Jahn is a professor of geochemistry at Université de Rennes 1 in France. He received his PhD degree from University of Minnesota, USA, and did post-doctoral research at the Johnson Space Center and Lunar Science Institute (Houston, 1972-76). His research involves applications of radiogenic isotopes and trace element geochemistry to a wide range of geological problems. More recently, he is engaged in isotope tracer study of ultrahigh-pressure metamorphic rocks from the Dabie orogen in China and in the Phanerozoic juvenile crustal growth in central Asia. He is the leader of IGCP 420-Continental Growth in the Phanerozoic: evidence from central Asia.

Fu-yuan Wu, received a Ph.D degree from the Changchun College of Geology in 1990, is now a professor of Geology at Changchun University of Science and Technology. $\mathrm{He}$ is specialized in petrology and petrogenesis of granitic rocks. As a Visiting Professor he has visited Université de Rennes in 1997 and1998 to work on problems of crustal growth in central Asia. His current research involves granite petrogenesis and Phanerozoic crustal growth in NE China.

Bin Chen is an associate professor of the Geology Department at Peking University, China. He was educated at Changchun College of Geology (B.Sc. and M.Sc.) and Peking University (Ph.D., 1991). His recent research interests include geochemical and isotopic studies of Phanerozoic granitoids from a variety of tectonic settings in China the Central Asian Orogenic Belt (northern Xinjiang and Inner Mongolia), continental collision zone (Dabieshan), and stable Archean craton (Taihang Mts.).
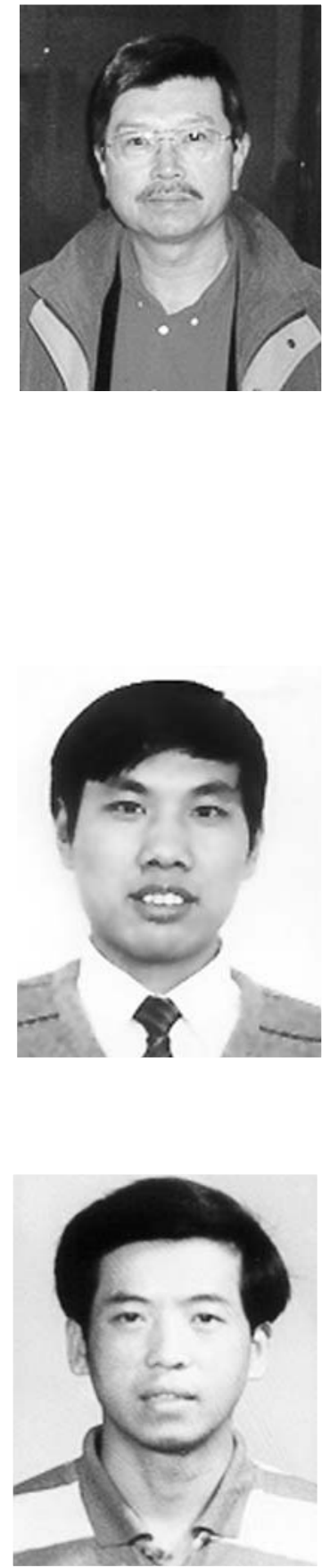